University of Nebraska - Lincoln

DigitalCommons@University of Nebraska - Lincoln

June 1993

\title{
Women, Economics, and the Concept of the Market: A Second Look at Reaganomics
}

Ann Mari May

University of Nebraska - Lincoln, amay1@UNL.edu

Follow this and additional works at: https://digitalcommons.unl.edu/cbafacpub

Part of the Business Commons

May, Ann Mari, "Women, Economics, and the Concept of the Market: A Second Look at Reaganomics" (1993). College of Business Faculty Publications. 23.

https://digitalcommons.unl.edu/cbafacpub/23

This Article is brought to you for free and open access by the Business, College of at DigitalCommons@University of Nebraska - Lincoln. It has been accepted for inclusion in College of Business Faculty Publications by an authorized administrator of DigitalCommons@University of Nebraska - Lincoln. 


\title{
Women, Economics, and the Concept of the Market: A Second Look at Reaganomics
}

\author{
Ann Mari May
}

Economic performance during the Reagan years fell far short of the hyperbole surrounding the $1980 \mathrm{~s}$. Touted as a period of robust economic expansion, in retrospect, the Reagan years did not produce unusually high growth in total output, resulted in relatively high overall unemployment rates, and ushered in a new era of increased economic instability [May, forthcomingl. During this period of disappointing growth, women and minorities became especially marginalized.

The Reagan reversion to "pro-market" policies in an age of corporate hegemony altered the structure of the economy and had a significant influence on some groups in society. In particular, "promarket" policies increased instability and accelerated the simultaneous decline of high-paying manufacturing jobs and the rise of poverty-wage employment. [Bluestone and Harrison 1982]. Reaganomics ushered in an era of economic instability with record rates of business and bank failures and farm foreclosures. This increased instability was accompanied by an attack on the social safety net [Pivon and Cloward 1985], which accelerated an increase in the incidence of poverty for women [Pearce 1978], or what has come to be known as the "feminization of poverty."

Although Reagan received relatively strong support from male voters both in terms of approval ratings and votes cast, women

The author is Assistant Professor of Economics, University of Nebraska, Lincoln. This paper was presented at the annual meeting of the Association for Evolutionary Economics, Anaheim, California, January 5-7, 1993. 
were often less than enthusiastic about the "Reagan Revolution." As the 1980 and 1984 elections demonstrated, a persistent gap existed in the support for Reagan, with women showing consistently more opposition to Reagan than men.

This paper examines the gap in support for Reagan between women and men and Reagan's response to this gap both in terms of his political strategy and his rhetoric. I conclude with a discussion of this response and the ways in which the "pro-market" orientation of the Reagan years worked to support a system of female oppression.

During the Reagan reign of the 1980s, a new term entered the lexicon of electoral politics that reflected a long-standing, yet little noticed, division in American society. "The gender gap," as it came to be known, referred to the differences between women and men on issues, party identification, and candidate selection [Matlack 1987; Shapiro and Mahajan 1986; Zipp and Plutzer 19851. This gender gap reflects a tendency for women to favor less military spending and more government spending on social services, to identify with the Democratic party, and to vote for Democratic over Republican candidates.

Although the gender gap gained national media attention only in the $1980 \mathrm{~s}$, it is not a recent phenomenon. According to Carol M. Mueller, President Warren Harding, sensing the importance of the newly gained women's vote, tried to placate a female electorate by appointing women to regulatory boards and judgeships [Mueller $1991,25]$. However, low voter participation rates among women relative to men soon convinced politicians that there was little to fear from women, electorally speaking. Although sophisticated polling techniques that emerged in the 1950s showed more clearly issue differences between men and women, relatively low female participation rates continued to provide solace to conservative politicians. However, it was in the 1980s that the gender gap revealed the growing potential political influence of women in presidential politics.

If presidential candidates were unaware of the significance of the gender gap before the 1980 presidential election, they soon discovered the potential significance of "a women's vote." For the first time in U.S. history, women's participation rates in the 1980 s exceeded that of men and gave candidates new reason to listen to the new majority. Moreover, President Reagan's gender gap was the largest of any postwar president, and a gender gap of six to eight 
percentage points persisted throughout the presidential elections of the 1980s [Kenski 1988, 48].

Before the 1980 election, however, the rise of women's potential political influence was not obvious to either the Carter or the Reagan campaigns. President Carter's pollster, Pat Caddell, later admitted the mistake of believing that "sex was a variable that it didn't pay to look at" [Doudna 1983, 159]. According to the Reagan campaign staff, the gender gap reflected little more than the "antiRepublicanism of Jewish women, Black women, and feminists" [Elshain 1984, 23].

The gender gap of the 1980 s reflected more, however, than just the dissatisfaction of left-leaning women. While feminists were most outspoken in their disgust of a president whom they later nicknamed "the caveman," disapproval remained widespread. In the 1982 congressional elections, a gender gap of 6 percent remained. By mid-1983, the president received "disappointing" or "poor" ratings from 45.1 percent of males polled compared to 70.8 percent of women ["The Gender Gap? Still a Problem" 1983, 47]. Even Republican women expressed their disapproval. In spring 1983, leaders of the National Federation of Republican Women told the president that in women's view, he fell "somewhere between being apathetic about women's issues and being antiwoman" [Gifelli 1984, 177]. In August 1983, a member of the president's own staff, Barbara Honegger, resigned in disgust from a project designed to identify and amend existing laws that discriminate against women, claiming that the program was a "sham" ["Sweet Nothings" 1983, 20].

When attempts to discredit Honegger as "a low level munchkin," whose most important task at the Justice Department was said to have been "to dress up as the Easter Bunny" at the White House Easter egg roll, mysteriously failed to improve the president's standing with women, Reagan appeared to be truly baffled ["Sweet Nothings" 1983, 20]. In July 1984, the president remarked, "[W] hen certain people for political reasons claim that I don't understand the modern woman, I'm tempted to say, "Then how come I have two very independent daughters"' [Gifelli 1984, 177]. Reagan's attempts to showcase appointments such as that of Elizabeth Dole as Secretary of Transportation, Margaret Heckler as Secretary of Health and Human Services, Jeanne Kirkpatrick as Ambassador to the United Nations, and Sandra Day O'Connor to the Supreme Court, appear to have failed to increase his sup- 
port. Finally, a "gender gap specialist" was called in to analyze the problem.

In 1984, the White House hired Linda A. DiVall to examine the gender gap problem using sophisticated polling techniques [Brackman and Erie 1986, 5]. Similarly, Decision/Making/Information, Reagan's main polling firm, conducted polls focused on women throughout 1983 and 1984 . These polls revealed that, not surprisingly, women were not a homogeneous group and that political attitudes and support for the president varied by age, marital status, and employment characteristics [Witt 1985]. The results of the polling indicated that the gender gap was greatest among single working women [Witt 1985, 51]. Post-election exit polls confirmed the demographic differences among women. The CBS News/New York Times Election Survey (1984) indicated that the gender gap was largest among single, young women with a college education, especially those with family incomes over $\$ 50,000$ a year [Kenski 1988,53 ].

As Democrats attempted to exploit the gender gap with the nomination of Geraldine Ferraro as vice president, the Reagan campaign moved to minimize the gap using the war and peace issue. According to Harold Brackman and Steven Erie, Reagan's "new-found noninterventionism" in early 1984 helped to belie women's fears that he was "trigger happy" [Brackman and Erie $1986,6]$. Publicizing early exit polls taken from a small sample that showed that the gender gap had narrowed to only 4 percent, the Republicans declared "the gap" a dead issue. As Elizabeth Dole put it, "I think we can declare the gender gap closed" [Brackman and Erie 1986, 6]. However, in the end, reports of the death of the gender gap had, like Mark Twain's celebrated death, been exaggerated. Later, more complete polls showed a gender gap of 6 percent, similar to that which had prevailed in 1980 [Brackman and Erie 1986, 6].

Although a gender gap in support for the president continued throughout the Reagan years, it received little attention in the press or from the president himself. The president initially responded to the gender gap by trying to rehabilitate his status with working women by appointing women to a few key administrative positions, but he soon settled on a strategy of divide and conquer. Exploiting focus groups and opinion poll data, the president increasingly spoke to women who identified with the conservative values of the religious right. Reagan's support of a 
"pro-market" ideology eventually led him away from policies of equal opportunity for women and toward policies that rewarded women for accepting a dependent and often unequal position in society.

The evolution of Reagan's response to the gender gap is beautifully symbolized in an often overlooked but revealing source of presidential rhetoric-the annual president's Mother's Day Proclamation. These proclamations reveal an early attempt to recognize the importance of women's work outside the home followed by a rhetorical shift to the right. As the Reagan years progressed, the proclamations reflected the growing importance of themes highly reminiscent of the early nineteenth century notion of the "Cult of True Womanhood."

In 1981, for example, the President acknowledged that many changes have occurred in the lives of American mothers: "Today they [women] are increasingly involved in business, politics, education, arts, sciences, and government as well as the vital work of the home and family" [Reagan 1982, 352]. In 1982, although less effusive, the president continued to acknowledge that "increasingly numbers of women have added outside paid employment to their traditional roles" [Reagan 1983, 437]. In 1983, mothers were even said to be "contributing vitally to the economy through their accomplishments at work" [Reagan 1984, 509]. However, from 1984 on, no mention was made of work outside the home. Although themes of "Republican Motherhood" were stressed throughout, the role of women was increasingly narrowed to that of raising children. In the president's words, "[A]lmost every woman in our Nation looks forward to the rewards and joys of motherhood without overlooking the long-term effort that raising children demands" [Reagan 1986, 453].

While the importance of mother's work outside the home was devalued in later proclamations, spiritual metaphors abound. Biblical references were absent from the early proclamations, but appear quite frequently in later proclamations. In 1986, Reagan quoted an old Jewish saying, with patriarchal elements intact, that "God could not be everywhere-so He created mothers" [Reagan 1988, 494]. In the 1987 Mother's Day Proclamation, in a statement with obvious pro-life overtones, Reagan reminded us that "there is no love like a mother's-she who carries the child that God knits in the womb" [Reagan 1989, 422]. Finally, in 1988, Reagan again invoked the Bible directly, proclaiming that the 
"mark of motherhood, as the story of Solomon ... shows, is a devotion to the well-being of the child so total that it overlooks itself and its own preferences and needs" [Reagan 1990, 514].

Reagan's response to the gender gap, both in terms of his political strategy and in terms of his rhetoric, demonstrates what presidential historian Theodore White describes as a fundamental aspect of Reagan's views: "His [Reagan's] idea, voiced so often in public, is that the best way forward may be found by going back" [Dallek 1984, 58]. This response to the gender gap of the 1980s tells us much about his view of the proper role of women in society as well as his overall economic philosophy. Just as a woman's role in society is to be conceived of in the nineteenth century concept of the "Cult of True Womanhood," Reagan's overall economic philosophy is to be understood in terms of nineteenth pro-market, antigovernment rhetoric. Moreover, Reagan's response reflects the relationship between the conservative reversion to pro-market policies and a paternalistic society that keeps women in their separate sphere.

That women have, in general, been less supportive of this return to the market than men should not be unexpected. Women have not benefited from the "free market" relative to men. In fact, pro-market policies provide little comfort to women who have historically been discriminated against by the market. Although the market is ostensibly gender neutral in theory, in reality it is not. Instead, the market reflects a set of social relations that are based upon custom and tradition. Moreover, these customs and traditions have reflected the values, priorities, and skewed perceptions of justice that are characteristic of a patriarchal society. Nowhere is this more evident than in the labor market.

In the theoretical sphere of mainstream economics, the wage rate is a gender-neutral concept resulting from the interaction of the supply and demand for labor. The market wage is simultaneously a result of the productivity and scarcity of labor, and wage discrimination is at best a temporary phenomenon subject to the discipline of the market. According to Alice Kessler-Harris,

Because the wage participates in social custom and practice, it embodies the lived realities of male and female sex roles, producing an abiding tension between a market that is said to distinguish only between workers' skills, education, and commitment on the one hand and a set of constructs that 
values sexual differences in various ways on the other [Kessler-Harris 1990, 4-5].

In reality, however, the wage rate is a result of political struggle-a social rather than a theoretical concept [Kessler-Harris $1990,5]$. Moreover, since the rise of market capitalism, the wage rate for men has embodied the primary means of self-realization. The wage rate became the measure of men's masculinity. For men, masculinity is associated with fulfilling a role as provider, which almost always has been interpreted in economic terms.

While wages represented a means of self-realization for men, they have been inversely related to our notions of femininity. For women, femininity is instead related to dependence, self-sacrifice, and family. A woman's wage has never functioned in any general way as a means to independence but has, as Kessler-Harris reminds us, "functioned to ensure attachment to family" [KesslerHarris 1990, 19].

Once again, the relationship between gender roles and economics is clearly reflected in Reagan's rhetoric by comparing Mother's Day with Father's Day proclamations. Whereas he describes mothers as "nurturers" who "support" and "sustain others" through "self sacrifice," fathers, above all else, "provide" and "protect" along with offering "leadership," "guidance," and "direction" [Reagan, various years]. More importantly, while women's work is ancillary to their primary role as nurturers, men's work is viewed as being essential to their identity. Women are defined in terms of what they are-loving, nurturing, supportive; men, however, are what they do, and wages are a measure of their success. Moreover, wages, for men, are a means to acquire the "love and honor of their children and the respect of their community" [Reagan 1989, 423].

The ultimate reversion to a dual-spheres notion on the part of the Reagan administration reflects the contradiction between true equality of opportunity and a pro-market policy orientation. Moreover, because mainstream economics has historically provided the intellectual rationale for the free market, its precepts are quite often at odds with groups that have been discriminated against by the "free market."

Economics as a discipline has, in large part, developed as a hypothetical deductive tradition rather than an empirically based social study. It relies upon abstract models that are rarely massaged by the "balm of experience" [Kessler-Harris 1990, 117]. The 
elaborate body of thought that provides a foundation for the theoretical core of economics is often at odds with the reality of economic life and quite often at odds with our notions of equal opportunity. Yet, it continues to maintain its hegemonic position.

The pretense of science, which economists have carefully cultivated, reinforces the authenticity of its conclusions and generally insulates economics from any untoward criticism that might be leveled against it. But the hegemony of mainstream economics, and its allegiance to the market, is more a result of its utility in rationalizing a particular distribution of wealth and income-a particular distribution of status and power. In this sense, mainstream economics functions as an "enabling myth," which preserves the status quo [Dugger 1989].

Heterodox economists have, of course, long been aware of the usefulness of the mainstream theoretical core in rationalizing a particular distribution of wealth and income. Yet, heterodox economists are only now exploring the ways in which these theoretical concepts are themselves gendered concepts. We have only begun to examine the ways in which these gendered concepts distribute power and status.

Reagan's approach to the gender gap reflects a fundamental contradiction between reliance on the market as a means of material reproduction and American values of equal opportunity-a contradiction that will no doubt provide a contested terrain in years to come.

\section{References}

Bluestone, Barry, and Bennett Harrison. The Deindustrialization of America. New York: Basic Books, Inc., 1982.

Brackman, Harold, and Steven P. Erie. "The Future of the Gender Gap." Social Policy 16 (Winter 1986): 5-11.

Dallek, Robert. Ronald Reagan The Politics of Symbolism. Cambridge, Mass.: Harvard University Press, 1984.

Doudna, Christine. "The 'Gender Gap'-Sending Tremors through Washington." Vogue, March 1983, pp. 159-162.

Dugger, William M. "Instituted Process and Enabling Myth: The Two Faces of the Market." Journal of Economic Issues 23 (1989): 607-15.

Elshain, Jean Bethke. "The Politics of Gender: Why Women Sound A Different Note." The Progressive, February 1984, pp. 22-25. 
Gifelli, Anna. "Showdown For Reagan At Gender Gap." Fortune, July 9, 1984, p. 177.

Kenski, Henry C. "The Gender Factor in a Changing Electorate." In The Politics of the Gender Gap: The Social Construction of Political Influence, edited by Carol M. Mueller, 38-60. Newbury Park, Calif.: SAGE Publications, Inc., 1988.

Kessler-Harris, Alice. A Woman's Wage: Historical Meanings and Social Consequences. Lexington, Ky.: The University Press of Kentucky, 1990.

Matlack, Carol. "Women at the Polls." National Journal 19 (1987): 3208-3215.

May, Ann Mari. "Economic Myth and Economic Reality: A Reexamination of the Carter Years." In Keeping Faith: The Presidency and Domestic Policies of Jimmy Carter. New York: Greenwood Press, forthcoming.

Mueller, Carol M. "The Gender Gap and Women's Political Influence." Annals of the American Academy of Political and Social Sciences 515 (1991): 23-37.

Pearce, Diana. "The Feminization of Poverty: Women, Work, and Welfare." Urban and Social Change Review 11 (1978): 28-36. Pivon, Frances Fox, and Richard A. Cloward. The New Class War:

Reagan's Attack on the Welfare State and Its Consequences. New York: Pantheon Books, 1985.

Reagan, Ronald. "Proclamation 4834-Mother's Day, 1981." In Public Papers of the Presidents of the United States: Ronald Reagan. Washington, D.C.: U.S. Government Printing Office, 1982 , p. 352.

. "Proclamation 4922-Mother's Day, 1982." In Public Papers of the Presidents. Washington, D.C.: U.S. Government Printing Office, 1983, pp. 437-8.

"Proclamation 5042-Mother's Day, 1983." In Public Papers of the Presidents. Washington, D.C.: U.S. Government Printing Office, 1984, p: 509.

. "Proclamation 5173-Mother's Day, 1984." In Public Papers of the Presidents. Washington, D.C.: U.S. Government Printing Office, 1986, p. 453.

"Proclamation 5466-Mother's Day, 1986." In Public Papers of the Presidents. Washington, D.C.: U.S. Government Printing Office, 1988, p. 493-4. 
. "Proclamation 5641-Mother's Day, 1987." In Public Papers of the Presidents. Washington, D.C.: U.S. Government Printing Office, 1989, p. 422.

"Proclamation 5801-Mother's Day, 1988." In Public

Papers of the Presidents. Washington, D.C.: U.S. Government Printing Office, 1990, p. 514.

"Proclamation 5642-Father's Day, 1987." In Public Papers of the Presidents. Washington, D.C.: U.S. Government Printing Office, 1989, p. 423.

Shapiro, Robert Y., and Harpreet Mahajan. "Gender Differences in Policy Preferences: A Summary of Trends from the 1960s to the 1980s." Public Opinion Quarterly 50 (1986): 42-61.

"Sweet Nothings." The Economist, September 3, 1983, p. 20.

"The Gender Gap? Still A Problem for Reagan." U.S. News and World Report, May 23, 1983, p. 47.

Witt, Evans. "What the Republicans Have Learned about Women." Public Opinion 8 (October/November 1985): 49-52.

Zipp, John, and Eric Plutzer. "Gender Differences in Voting for Female Candidates." Public Opinion Quarterly 49 (1985): 179-97. 